\title{
ETV6/ACSL6 Fusion Gene
}

National Cancer Institute

\section{Source}

National Cancer Institute. ETV6/ACSL6 Fusion Gene. NCI Thesaurus. Code C99415.

A fusion gene that results from a chromosomal translocation $\mathrm{t}(5 ; 12)(\mathrm{q} 31 ; \mathrm{p} 13)$ which fuses exon 1 of the ETV6 gene out-of-frame to either exon 1 or exon 11 or to the 3' untranslated region of the ACSL6 gene. This rearrangement was observed in one patient with refractory anemia with excess blasts with basophilia, one patient with acute myelogenous leukemia with eosinophilia, and one patient with acute eosinophilic leukemia 